\title{
Discovery of UPSTREAM of FLOWERING LOCUS C (UFC) and FLOWERING LOCUS C EXPRESSOR (FLX) in Gladiolus XHybridus, G. Dalenii
}

\author{
Jaser A. Aljaser \\ University of Minnesota \\ Neil Anderson ( $\nabla$ ander044@umn.edu ) \\ University of Minnesota \\ Andrzej Noyszewski \\ University of Minnesota
}

\section{Research Article}

Keywords: Flowering, Geophyte, Iridaceae, FLC, FRI

Posted Date: November 17th, 2021

DOI: https://doi.org/10.21203/rs.3.rs-1044399/v1

License: (c) This work is licensed under a Creative Commons Attribution 4.0 International License.

Read Full License 


\section{Abstract \\ Background.}

Gladiolus is a geophytic floricultural crop cultivated for cut flower and garden ornamental uses. Monocotyledonous flower crops have few, if any, flowering genes identified. Ornamental geophytes such as gladiolus, lily, tulip and daffodil are examples of floral crops that are currently being investigated to understand the flowering pathway. While the flower genes and environmental / hormonal factors leading to flowering are established in Arabidopsis, the lack of identified flowering genes in economically important ornamental geophytic crops, such as gladiolus, is critical to further genetic research. Thus, the importance of such an ornamental crop that relies on flowers (flowering) for economic purposes encourages researchers to discover the flowering genes to breed vigorous, flowering cultivars. The understanding of the flowering mechanisms in the flowering pathway is also of paramount importance.

\section{Results.}

Herein we show the discovery of UPSTREAM OF FLOWERING LOCUS C (UFC) and FLOWERING LOCUSC EXPRESSOR (FLX) genes in Gladiolus xhybridus and G. dalenii. The UFC gene is adjacent to FLOWERING LOCUS C $(F L C)$ which is a floral repressor in many temperate species. The $F L X$ gene upregulates $F R I G I D A$ $(F R I)$ which upregulates FLC expression. Discovery of both genes is a step forward in finding the FLC gene in gladiolus, provided they are linked. Seventeen gladiolus genotypes, consisting of early flowering and commercial cultivars, were discovered to possess the UFC gene, consisting of four exons in two allelic forms. The sequenced UFC gene, when translated into its amino acid sequence and set in pairalignment to other species, has up to $57 \%$ in amino acid identity to Musa acuminata. The UFC protein ranges in identity with pair-alignment to other monocot species, also with $57 \%$ amino acid identity to $M$. acuminata. The $F L X$ gene in gladiolus has 3/5 (60\%) exons in common relative to Ananas comosus, i.e. lacking 2 exons and a partially complete gene sequence; the pair-alignment of the three exons shows an overall $\sim 65 \%$ identity of $F L X$ to $A$. comosus. The UFC protein consists of a conserved domain, DUF966, which is higher in identity (86\%) and pair-alignment with Elaeis guineensis.

\section{Conclusions.}

The two newly-discovered genes in gladiolus, UFC and FLX, provide insight to further our understanding of the flowering mechanism, flowering pathway genes, and vernalization response in ornamental geophytes. This knowledge will be valuable for gladiolus breeders and geneticists to finding the FLC gene, identify segregating seedlings for both UFC and $F L X$, and aid in marker assisted selection for flowering gene expression.

\section{Background}


In angiosperms or flowering plants, "Florogenesis" is the transitioning process in a plant's apical meristem from vegetative tissue to reproductive organs or flowers [1]. This transition is governed by flowering genes in which expression is influenced by factors such as vernalization, photoperiod, gibberellins, an autonomous pathway and ambient temperature [2]. In Arabidopsis, several flowering genes have been discovered which are involved in flowering and act as floral integrators. These flowering genes include $F T, S O C 1, C O, V R N 1, P P D, F C A, F L D$, and $F L K$ [3-4]. These floral integrator genes specifically upregulate flowering by promoting transition from vegetative to flowering or repressing floral repressor genes. Repressor genes act as repressors of floral integrator genes and upregulate the expression of repressors, including genes such as FLC, FRI, FLX, VRN2, and SVP [3, 5-6].

FLOWERING LOCUSC (FLC) and FLC-like are floral repressors found in many dicotyledon plants, such as Malus [7], Rosa [8], Coffea [9] and Brassica [10]. The FLC gene is regulated by temperature changes throughout the year, both in annuals and perennials. In summer, $F L C$ expression is upregulated through FRIGIDA (FRI) by binding the FLC promoter through the DNA-binding protein SUPPRESSOR OF FRIGIDA4 SUF4 [11]. In addition, FR/ expression is upregulated by the FLOWERING LOCUS C EXPRESSOR (FLX); both SUF4 and FLX are in the FRI-specific pathway [12]. In winter, FLC is down-regulated through a process of vernalization as prolonged exposure of low temperature in winter in the meristem gradually reduces the expression of FLC [13]. In addition to the vernalization pathway, the autonomous pathway reduces the expression of $F L C$ both in the meristem and leaves [13]. Gradual reduction of FLC allows FLOWERING LOCUS T $(F T)$ to be expressed in the leaves and transported through phloem to reach to the meristematic tissue to stimulate the MADS box genes, thereby inducing flowering in Arabidopsis [14].

In wheat and barley, the flowering pathway is regulated by photoperiod, vernalization and the circadian clock [15]. Vernalization gene-2 (VRN2) is a dominant repressor or inhibitor of flowering in winter wheat (Triticum aestivum; a monocot grass) that is down-regulated by vernalization (a cold period; winter) [15]. Subsequently, the floral integrator leads to flowering in winter wheat while spring wheat doesn't require vernalization due to a non-functional VRN2 gene. However, vernalization is a facultative stimulus for earlier flowering in spring wheat [16]. In contract, maize (Zea mays) and rice (Oryza sativa) rely on plant age to build up sufficient energy requirements in order to transition to flowering through epigenetic action of miR172 [17]. In monocot geophytes (defined as herbaceous perennial plants with underground storage organs, e.g. bulbs, corms, tubers, etc., that promote winter survival), such as Gladiolus, Lilium, Tulipa, Narcissus and Crocus, the flowering pathway is poorly understood. Factors of plant growth influencing flowering in commercial geophytes for commercial production are well known [18] and include photoperiod, light intensity, the autonomous pathway, gibberellins, ambient and cool temperatures (vernalization) [1]. A clearly delineated genetic pathway for monocots (ornamental and otherwise) is still in the early stages of the discovery and characterization for many floricultural crops, such as gladiolus. In contrast, the Arabidopsis model is readily applicable to temperate dicotyledon plants [19] and may be only partially useful for monocots. Only a few flowering genes have been discovered in monocot ornamental geophytes [1], such as FT-like in Allium cepa [20-21], FT in Narcissus [22], NLF in Narcissus [23], $L F Y$ in Allium sativum [24-25] and in Lilium [26]. Recently, many flowering genes have been discovered in Lilium $\times$ formolongi ( $F T, C O$-like, AP2, GA1, SOC1) and/or proposed for L. formosanum 
(VER1, VER2) [27-28]. The discovery of flowering genes in geophytes serve as valuable resources to model flowering pathway(s) therein.

Geophytes such as Gladiolus, Lilium, Tulipa, Narcissus and Crocus are floricultural crops with ornamental value wherein flowering is essential to maintain the marketing value for these crops. Gladiolus $\times$ hybridus Rodigas, commonly known as gladiolus(-i), is commercially cultivated as a cut flower and as garden or landscape plants. Gladioli are geophytic plants with underground modified stem structures known as corms, producing cormels as a means of vegetative propagation [29]. Flower initiation and development are crucial steps for its success as a cut flower. Therefore, understanding the flowering pathway is vital for genetics and breeding to improve the floral market value.

Gladiolus has a genome size of $1100 \mathrm{Mbp}$, although it is unclear whether this is for haploid or diploid and the species is unknown [30]. The genome weight for gladiolus was recently measured in G. communis as 0.67-0.68 pg for monoploid G.s. (1Cx, pg) and in G. italicus at $0.61 \mathrm{pg}$ for monoploid G.s. (1Cx, pg) [31]. The limited knowledge of the gladiolus genome is also reflected in lack of knowing gladiolus flowering genes, there are no flowering genes discovered in gladiolus except for the gibberellin receptor gene GID1a in gladiolus [31]. However, the relationship of GID1a with flowering has not been established. In Arabidopsis, gibberellin binds to the gibberellin receptor forming GID1 complex that binds to DELLA, causing its degradation, thereby enabling $S O C 1$ and $\angle F Y$ to be upregulated, leading to flowering [32-33].

Understanding the flowering pathway and gene expression is important for efficient selective breeding of gladiolus for rapid generation cycling (RGC) or early flowering types that flower in $\leq 1$ year from seed [43]. An important flowering gene is $F L C$, a major flowering repressor found in Arabidopsis and many dicot species; FLC plays vital role in the control of flower initiation [13]. Gladiolus is a monocot genus (Iridaceae) with both summer and winter flowering species; $F L C$ has not been identified herein. It had been hypothesized that there is no FLC gene in monocot species until the FLChomologue was discovered in some cereal crops, such as Triticum aestivum [34], Hordeum vulgare [35] and Brachypodium distachyon [36]. These $F L C$ homologue studies did not discover $F R /$ genes, which upregulate $F L C$ expression in Arabidopsis thaliana [11]. A hypothesis to test would be that some monocots do not possess the flowering repressor $F L C$ gene and rely on alternative gene(s) to acts as a repressor(s) miR172 through epigenetic in plant age-dependent of Zea and Oryza [17]. Additionally it remains unknown whether there is FLC-dependent pathway in all monocots.

In Arabidopsis, FLC is located between two flanking genes, UPSTREAM OF FLOWERING LOCUS C (UFC, located $4.7 \mathrm{~Kb}$ upstream of FLC) and DOWNSTREAM OF FLOWERING LOCUSC (DFC, found $6.9 \mathrm{~Kb}$ downstream of $F L C$ ) [37]. The UFC gene expression is repressed by vernalization, independent of $F L C$ repression due to vernalization [37]. Thus, both $F L C$ and UFC are repressed by vernalization, yet are not dependent on each other for expression; the suppression is through chromatin modification in an epigenetic manner [37]. The VRN1 gene is expressed with vernalization and acts as a floral integrator whereas UFC is repressed and required by VRN1 expression dependently [38]. The potential role for UFC in flowering has yet to be discovered and it may not involve flowering at all since vernalization only 
represses UFC in seeds while DFC is repressed by vernalization of the plant [38]. Insertion of the NPTII gene between the UFC and FLC region confirmed NPTI/ response to cold as the whole cluster region of $F L C$ responded to cold [37]. In the UFC protein of $A$. thaliana, a conserved domain, DUF966, has 92 amino acids, although its function is still unknown [39]. This lack of knowledge in DUF966 function creates a challenge to identify the function of UFC protein. However, a recent study shows the role of UFC in $A$. thaliana, with the gene SOK2, which appears to have a role in embryogenesis, root initiation, growth and branching of the primary and lateral roots [39]. The conserved domain DUF966 is reported to be present in the OSDSR gene family of Oryza sativa [40]. The promoter for genes that contain DUF966 have a defense-stress response to pathogens, salicylic acid, jasmonate, drought or salinity [41]. The ZmAuxRP1 gene which promotes the biosynthesis of indole-3-acetic acid (IAA) to increase resistance against pathogens in Zea mays [41]. Thus, all the genes that contain DUF966 vary in function but all of them are triggered by environmental or stress stimuli to overcome an undesirable change influencing plant growth and development.

The $F L X$ gene encodes a putative leucine zipper domain which is required for $F R$-mediated activation of FLC in Arabidopsis [42] (Fig. 1). Up-regulating FLC occurs in winter annual Arabidopsis [33], while late flowering phenotypes exhibit strong expression of $F L X$ which indicates a role of $F L X$ in the suppression of flowering [42]. Several genes have been discovered in the FLX gene family, e.g. FLX-LIKE1 (FLL 1), FLXLIKE2 (FLL2), FLX-LIKE3 (FLL3), FLX-LIKE4 (FLL4) [11,33]. FLX and FLL4 are the most crucial genes in flowering time control in Arabidopsis [33].

In order to test whether $F L C$ is present in gladiolus, the adjacent gene (UFC) will also be probed, along with FLX which is part of the FLC-dependent mechanism. Therefore, the objective of this study is to identify whether UFC and $F L X$ genes occur in the genetically diverse gladiolus germplasm of the University of Minnesota Gladiolus Breeding Program. The null hypotheses tested are: $\mathrm{H}_{0} 1=$ There is no difference among gladiolus genotypes in the existence of the UFC gene; $\mathrm{H}_{0} 2=$ There is no difference among gladiolus genotypes in the presence of $F L X$.

\section{Results}

The investigated genotypes of Gladiolus resulted from the gladiolus breeding program for the selection of rapid generation cycling, which includes 14 breeding genotypes and 3 commercial cultivars ('Vista', 'Glamini®' and 'Carolina Primrose'; Table 1). Rapid Generation Cycling (RGC) in gladiolus is the ability of flowering in the first year from seed as an annualized perennial [43-45]. Classically, seed-propagated gladiolus have 3-5 years as juvenile, non-flowering (vegetative) seedlings before a phase change into flowering (reproductive) adults [44]. The University of Minnesota Gladiolus breeding program developed such gladiolus genotypes with a reduced juvenility period and phase change to flowering in $\leq 1$ year from seed [43-45].

The designed probe for the UFC gene in Gladiolus (RAPiD genomics ${ }^{\circledR}$ LLC; Gainesville, FL; http://rapidgenomics.com/home/) resulted in a total of 433 sequences; $161 / 433$ sequences had read hits of the UFC 
gene with various percentages of coverage. Of these, 34 selected sequences were chosen for this study, based on the largest length with two sequences per genotype due to presence of two alleles per genotype. These sequences represent the genomic sequence of UFC in gladiolus. The sequences were analyzed for gene prediction using the HMM-based gene structure prediction of FGENESH using $A$. thaliana (Generic) as the specific gene-finding parameter since the gene prediction is optimized for $A$. thaliana. Results confirmed the presence of UFC exons of a protein and coding sequence. The UFC coding sequences of each gladiolus genotype were analyzed in Genoeious ${ }^{\circledR}$ by pair-alignment with its genomic sequence to determine each exon. After the pair-alignment, the Coding sequence was then translated and aligned in multi-alignment process using MUSCLE alignment in the neighbor joining clustering method and CLUSTALW sequencing scheme with UFC proteins of other monocot and dicot species: Ananas comosus, Musa acuminata, Elaeis guineensis, Asparagus officinalis, Arabidopsis thaliana and Glycine max. The UFC gene in Gladiolus $\times$ hybridus was assigned to GhUFC as a label while genotype $14, G$. dalenii 'Carolina Primrose', is assigned to GdUFC.

There are two alleles of the UFC gene found in gladiolus, designated as $\mathrm{A}$ and $\mathrm{B}$. Thus, the genes are designated as GhUFC-A and GhUFC-B. The median number of amino acids of GhUFC-A protein is 420 amino acids across all gladiolus genotypes, with some genotypes having less than 420 amino acids. One genotype has 451 amino acids which could be due to an insertion, while GdUFC-A also has 420 amino acids. The second allele, GhUFC-B protein has a range of 375 to 410 amino acids, GdUFC- $B$ has 286 amino acids with an incomplete protein, missing many amino acids and a stop codon (Figs. 2, 3). Gladiolus genotypes 1 (G. xhybridus 21213; Table 1) and 15 (Gladiolus $\times$ hybridus 'Beatrice'; Table 1) were selected for pair-alignment with the species of comparison (Table 2). Similarities of identity protein sequences and the percentage of GhUFC-A and GhUFC-B occur at range of $\sim 30-57 \%$ across all species (Table 2). The intron-exon organization of GhUFC-A in Gladiolus $\times$ hybridus 'Beatrice' (genotype 15; Table 1 ) is similar to Elaeis guineensis and Asparagus officinalis in term of exons splicing (Fig. 4) while GhUFC$B$ in $G$. xhybridus 21213 (genotype 1; Table 1) has some similarity with Ananas comosus exons splicing. The remaining genotypes fall into these two configurations of the exon; the configuration shows the location of the conserved domain for UFC gene DUF966, which is found in Arabidopsis and other selected species of comparison. The DUF966 domain has the 92 and 93 amino acids of Ananas comosus. The multi alignment of the UFC protein conserved domain is overall conserved across species, although it is polymorphic (Fig. 5). With the high identity matching in Gladiolus genotypes 1 and 15 exhibit a range of $\sim 65 \%$ to $~ 86 \%$ across all investigated species for the DUF966 domain of the UFC protein (Table 3 ). The GhUFC-A allele has a high identity across gladiolus genotypes (Fig. 6), with the polymorphic exception of G. $\times$ hybridus 2231 (genotype 3; Table 1) and G. × hybridus 3931 (genotype 7). GhUFC-B is also conserved and identical in sequence with $G$. xhybridus 20732 (genotype 12), due to missing amino acids.

The FLX gene was identified in Gladiolus in 12/17 genotypes; 11 Gladiolus $\times$ hybridus genotypes have GhFLX whereas GdFLX is identified in genotype 14, G. dalenii 'Carolina Primrose' (Table 4). The range of amino acid proteins are from 146 to 254 amino acids missing the stop codon. Three genotype sequences in G. ×hybridus 2231, 3923, and 'Glamini' $($ (genotypes 3, 6 and 16, respectively; Table 1) have the longest amino acid chain. $F L X$ is present in many species; in Arabidopsis it belongs to $F L X$ gene family, $F L X$, 
FLOWERING LOCUS C EXPRESSOR-LIKE 1 (FLL1), (FLL2), (FLL3) and (FLL4) [33]. Based on the pairalignment, GhFLX and GdFLX matches FLL 1 with as high as $50 \%$ in amino acid identity (Table 4). The similarities of sequences in identity of gladiolus genotypes range from $\sim 26 \%$ to $\sim 65 \%$ across all investigated species of the entire FLX protein; the highest identity is in Ananas comosus match with $\sim 65 \%$. The multi-alignment for all $F L X$ indicates that the tested gladiolus genotypes with the longest amino acid sequences lack exons (Fig. 7). A pair-alignment test with Ananas comosus - FLX reveals that GhFLX G. xhybridus 'Glamini'® (genotype 16; Table 1) lacks two exons and a stop codon (Fig. 8).

\section{Discussion}

The presence of a putative UFC gene in gladiolus is confirmed with two alleles, GhUFC-A and GhUFC-B. It is highly possible that allelic number is due to tetraploidy in cultivated gladioli $(2 n=4 \times=60)$ [46-48]; ploidy levels of $G$. dalenii have not been reported [46]. The cultivated Gladiolus $\times$ hybridus are interspecific hybrids [49]. Therefore, the presence of different alleles would be expected in the diverse array of genotypes included in this study: 13 are from University of Minnesota gladiolus breeding program (interspecific hybrids) and four are commercial gladiolus cultivars with unknown ancestry and relatedness (Table 1). The GhUFC-A gene has $~ 50 \%$ identity with Musa acuminata, Elaeis guineensis and Asparagus officinalis (Table 2). The splicing of Elaeis guineensis and Asparagus officinalis exons is similar to GhUFC-A (Fig. 4). GhUFC-B gene splicing in the first 4 exons is similar to Ananas comosus, Arabidopsis thaliana and Glycine max UFC gene splicing (Fig. 4). These divergences in splicing of the UFC gene support UFC presence in gladiolus with two alleles [46]. Further tests should be done to identify whether or not UFC is also present in diploid gladiolus species, such as G. murielae, G. tristis and $G$. carneus since these three species are diploids [50].

The UFC gene is responsive to vernalization by lowering expression alongside $F L C$ and $D F C$ in Arabidopsis thaliana, as all these genes are in the cluster of vernalization stimulus region [37]. $F L C$ is a floral repressor, the overexpression of $F L C$ results in a delay in flowering [51], while overexpression of UFC does not result in the altering flowering time [37]. Thus, UFC is adjacent to $F L C$, both are repressed by vernalization, yet UFC does not show any influence in flowering time. This was observed herein since the genotypes in this study include both RGC-1, which are early flowering gladiolus able to reach flowering in the first year from seed and the classical later-flowering gladiolus which requires 3-5+ years to flower from seed. The multi-alignment of UFC protein in RGC-1 genotypes does not show any difference from non-RGC-1 genotypes. Thus, the UFC gene most likely isn't involved in flowering, at least directly which was proven in a UFC study in A. thaliana [38]. The main differences (Fig. 6) represent the differences between alleles of UFC-A and UFC-B, regardless of the gladiolus genotypes tested herein (Fig. 6).

During the winter cold period, vernalization suppress both FLC and UFC expression [37], which allows floral gene integrators to promote flowering. The hypothesis would be that, after vernalization and flowering, the UFC protein involvement is in embryogenesis and root initiation such that growth and branching occur in the spring season (since it doesn't occur in the winter season). This could explain how 
FLC and UFC are both negatively responsive to vernalization stimuli in the cluster genes area, while upstream of UFC is not responsive to vernalization [37].

The identification of $F L X$ in gladiolus raises the question whether gladiolus follows the Arabidopsis dicot model of the flowering pathway. In the winter annual, $A$. thaliana, flowering is promoted after vernalization, which suppresses the floral suppressor $F L C$ that is upregulated by $F R /$ through activation of $F R /$ complex of ( $F R I, F R L 1, F R L 2, F E S 1$ and SUF4) proteins in addition to $F L X$ protein. $F L X$ was proven to provide transcriptional activity for the $F R /$ complex [11]. A loss of function of $F L X$ in $A$. thaliana resulted in early flowering phenotypes [42], which indicates the clear role of $F L X$ in flowering. The role of $F L X$ in gladiolus has not been tested, particularly in RGC-1 genotypes and pedigrees; thus, FLX upregulation of $F R /$ in gladiolus would be a rational approach. However, $F R /$ was not detected in gladiolus, using the primer design of $A$. thaliana FRI (At4g00650) because the $F R /$ gene has not been previously detected in any monocotyledon species. Thus, the primer used is from $A$. thaliana, the test did not detect $F R /$ gene in all of the 17 gladiolus genotypes without finding a single match [45]. Our results with gladiolus provide additional data in support of these previous results for $F R /$ in monocots. In addition, $V R N 2$, the repressor of flowering in cereals and $A$. thaliana was not detected in gladiolus, using the primer design of Triticum monococum, T. durum and Hordeum vulgare ([45]; Appendices A1, A2 and A3). This is not conclusive evidence as the genetic similarities between $A$. thaliana and Gladiolus are low, given that GhUFC-A is $\sim 32 \%$ and GhFLX is 50\% identical to $A$. thaliana genes. Therefore, there could be an FR/gene in gladiolus but this would require better primer design to locate the gene because the presence of GhFLX might indicate in the presence of other flowering repressor genes as $F R /$ protein upregulates $F L X$ in $A$. thaliana and is part of the flowering pathway [11]. In addition, Musa acuminata, Elaeis guineensis and Ananas comosus are all monocots and tropical species which have FLX and SUF4 genes as part of the FRI complex [51]. This indicates the presence of some of the $F R /$ complex components while a lack of identification of $F R /$ gene itself creates divergent possibilities: a) either there are $F R /$ and $F L C$ genes in these species or $b$ ) a lack of these genes and the presence of SUF4 and FLX genes have other unknown flowering pathway purposes. Since GhFLX and GdFLX have similarities to $F L L 1$, reaching up to $50 \%$ identity in amino acids, $F L X$ gene is part of the gene family, $F L L 1-F L L 4[11,33]$. While the role of $F L L 1$ in flowering pathway is not proven, $F L X$ and $F L L 4$ are the most crucial genes in control of flowering time in Arabidopsis [33]. Additionally, the relationship between UFC and FLX indicates that a mutation in FLX influences UFC expression, e.g. the $f x$ mutant in A. thaliana [42].

The next step in this research would be to identify the UFC gene in diploid gladiolus species to determine if the allele is similar to GhUFC-A, GhUFC-B or a third different allele. Use of diploids would simplify the study to determine the function of UFC protein in gladiolus by silencing and knocking out the gene. Locating the physical location of the UFC gene in Gladiolus will help in testing if there are other UFC genes in gladiolus as part of a UFC gene family, since the first discovered UFC gene (At5g10150) in A. thaliana is located in the cluster genes UFC, FLC and DFC on chromosome 5 [37]. UFC is also designated SOK2 and the other UFC genes are grouped in SOK gene family such as SOK1 (At1g05577), SOK3 (At2g28150), SOK4 (At3g46110) and SOK5 (At5g59790) [39]. 
Identifying the FLX gene in Eurasian species of Gladiolus, particularly G. italicus, G. imbricatus and G. communis, would be informative since these winter-hardy, perennial species grow in temperate habitats that require vernalization to break corm dormancy in the winter season [29, 52-53]. Conversely, identifying $F L X$ in subtropical gladiolus species, such as $G$. crassifolius, G. laxiflorus and $G$. atropurpureus [54], would allow comparison of $F L X$ among these different habitats to further support the influence in $F L X$ in the flowering pathway. Furthermore, the use of transgene silencing of $F L X$ in gladiolus would determine whether or not $F L X$ influences the production of a rapid flowering phenotype gladiolus (RGC-1), as was reported in the loss of flx function in A. thaliana [42]. In conclusion, the discovery of UFC and $F L X$ genes in gladiolus provides insight into understanding flowering and vernalization responses in ornamental, monocot geophytes.

\section{Conclusions}

Rapid generation cycling is a powerful tool that can be implemented to reduce the juvenility period in perennial crops such as gladioli and are being applied in the breeding program ideotype. Although it is possible to annualize a perennial crop through genetically modifying the flowering pathway by overexpression a positive flowering regulator or inserting blocker of flowering suppressor, such biotechnological methods require regulatory approval. Therefore, conventional breeding methods for early flowering are widely accepted and do not require regulation for cultivar release.

The search for $F L C$ and its regulatory genes in gladiolus is a step to uncover the flowering pathway in geophytes. To uncover if $F L C$ is present in Gladiolus, we searched for linked genes with $F L C$. In Arabidopsis, FLC is adjacent to two genes, UPSTREAM OF FLOWERING LOCUS C (UFC) and DOWNSTREAM OF FLOWERING LOCUS C (DFC), both of which are downregulated by vernalization. The discovery of UFC in gladiolus as well FLX (which upregulates FRI) is crucial to establish the flowering pathway. These may be early indicators of the presence of $F L C$ homologue in gladiolus. Discovery of both genes are important to understand the flowering mechanism and genes in the flowering pathway to aid in breeding and selection of early flowering gladioli from seed or corms (Appendix A4).

\section{Methods}

\section{Germplasm}

The 17 gladiolus genotypes used in this study (Table 1) were chosen to represent a range of diversity within cultivated gladioli (Gladiolus $\times$ hybridus, $G$. dalenii) which includes nine genotypes of Rapid Generation Cycling-1 (RGC-1; ones that flower in $\leq 1$ year from seed; [43-45]) and eight genotypes Non-RGC genotypes (that require 2 to 5 years to flower from seed). Fourteen of these genotypes are interspecific parents and hybrids created by the University of Minnesota Gladiolus Breeding Program, while three additional genotypes are commercial cultivars. One genotype 'Carolina Primrose' is derived from the species G. dalenii (Table 1). All gladiolus pedigrees used in this experiment are published [43-45] and commercial cultivars 'Beatrice' (an open-pollinated seedlings of unknown origin, occurring in a private 
garden, Brookfield, Vermont, in 2003). 'Beatrice' was selected for its winter hardiness, surviving in USDA Z3). 'Glamini' ${ }^{\circledR}$ a series of shorter in height than tall summer gladiolus, bred by Dutch breeders, bloom early, has a range of flowering colors [55]. 'Carolina Primrose' is an heirloom gladiolus, bred in 1908, yellow color flowers, collected at an old homesite in North Carolina; it is a cultivar bred from G. primulinus [56].

\section{Greenhouse Environment}

Mature gladiolus corms (competent to flower) were planted into $1679.776 \mathrm{~cm}^{2}$ square, deep pots (Belden Plastics, St. Paul. MN) in week 23 (2017) and grown for 18 weeks. Containers were filled with SS\#8-F2RSi potting soil, "SunGrow" (Sun Gro Horticulture, Agawam. MA). The corms were grown in a long day photoperiod ( $0800-1600 \mathrm{HR}$ supplied by $400-\mathrm{W}$ high-pressure sodium lamps +2200 to $0200 \mathrm{HR}$ night interruption, $>150 \mu \mathrm{mol} \mathrm{m}{ }^{-2} \mathrm{sec}^{-1}$ ) at a minimum setpoint of $18^{\circ} \mathrm{C}$ (day/night), $70-80 \%$ relative humidity, with irrigation accomplished using constant liquid feed (CLF) of $125 \mathrm{ppm} \mathrm{N}$ from water-soluble 20N4.4P-16.6K (Scotts, Marysville, $\mathrm{OH}$ ) and deionized water on weekends. Standard fungicide drenches and insecticides were applied either monthly or as needed, respectively.

\section{DNA extraction and probe design}

Newly expanded gladiolus leaves were harvested, placed in an ice box and sent to RAPiD Genomics ${ }^{\circledR}$ LLC (Gainesville, FL; http://rapid-genomics.com/home/) for DNA extraction, probe design, sequencing and computable analysis. Probe designs for the UFC gene were based on banana, Musa acuminata subsp. malaccensis accession XM_009383889, from the GenBank Nucleotide Core [57] and oil palm, Elaeis guineensis accession XM_010920607.2 [58]. Probe design for FLX gene were based on oil palm, Elaeis guineensis accession XM_010924316.2 [59] and date palm, Phoenix dactylifera accession XM_008801571.2 [60]. The designed probe for UFC able to capture the locus in Musa acuminata and Elaeis guineensis by capturing the $2 x$ coverage of the UFC exons in Musa acuminata and Elaeis guineensis, while the FLX probe captures the locus in Elaeis guineensis and Phoenix dactylifera. Probes are amplified in short reads of UFC and $F L X$ genes in gladiolus. The reads are sequenced through Illumina dye sequencing technique, the raw data is demultiplexed using Illuminas BCLtofastq then assembled using MaSuRCA $®$ software [61], creating full assembly sequences scaffolds. Afterwards, read mapping using the reference genome and blast to filter all assembled sequences for hits to the sequences provided for probes design (UFC and FLX), then count read numbers for each assembled sequence passed the filtering, accruing the final sequences for genetic analysis. Gene sequences are currently being deposited into GenBank.

\section{Genetic Analysis}

The sequence data for the UFC and FLX genes used in this study were found in the genetic sequence database under the following accession/ID numbers: Ananas comosus (Aco009327) UFC gene is from the Pineapple Genomics Database [62]; Musa acuminata (GSMUA_Achr5T28540_001) UFC from the Banana Genome Hub [63]; Elaeis guineensis (p5.00_sc00099_p0095) UFC from the Malaysian Oil Palm 
Genome Programme [64]; Asparagus officinalis (evm.model.AsparagusV1_08.3493) UFC from the Asparagus Genome Project [65]; Arabidopsis thaliana (At5g10150) UFC from The Arabidopsis Information Resource (TAIR) [66]; Glycine max (Glyma.11G193000.1) UFC from the SoyBase [67]. The $F L X$ protein was from the GenBank Nucleotide Core with accession numbers as follows: Ananas comosus (XP_020095672.1) [68], Musa acuminata (XP_009420070.1) [69], Elaeis

guineensis (XP_010922618.1) [70], Arabidopsis thaliana - FLX(NP_001154541.1) [71], Arabidopsis thaliana - FLL 1 (NP_566492.1) [72], Arabidopsis thaliana - FLL2 (NP_001320766.1) [73], Arabidopsis thaliana - FLL3 (NP_564678.1) [74], Arabidopsis thaliana - FLL4 (NP_001119474.1) [75] and Glycine $\max$ (Glyma.15g269300) FLX from the SoyBase [67].

Generated sequences were analyzed for gene prediction using the HMM-based gene structure prediction of FGENESH with Arabidopsis thaliana (Generic) as the specific gene-finding parameter. The predicted genes for UFC and $F L X$ were analyzed in multi-alignment using Geneious $\odot$ software (Biomatters $L t d$, Auckland, NZ). The UFC protein sequences of gladiolus were analyzed for conserved domains using the Protein Homology/analogy Recognition Engine V 2.0 (Phyre2) browser [76]. Then the alignment of conserved domain was formed to compare the matching and differences in each amino acid in the sequences of gladiolus and the other comparison species. A phylogenetic tree of all UFC genotypes of Gladiolus was formed by computing the distances using the Tamura-Nei method and were in the units of the number of base substitutions per site. The tree building used the Neighbor-Joining method and a bootstrap test was performed for each tree (500 replicates).

\section{Declarations}

\section{Ethics approval and Consent to participate}

All Gladiolus plant material was obtained from the University of Minnesota Gladiolus Breeding Program or from commercial vendors that possessed the propagation rights for the germplasm. Fresh leaf samples were harvested from plants growing in the University of Minnesota Plant Growth Facilities.

\section{Consent for publication}

Not applicable.

\section{Availability of data and materials}

The DNA sequences produced are being deposited in the NCBI GenBank data (https://www.ncbi.nlm.nih.gov/nuccore/).

\section{Competing interests}

The authors declare that they have no competing interests.

\section{Funding}


Funding for this research was supported by grants from the Minnesota Agricultural Experiment Station (MAES21-0045) and the Minnesota Gladiolus Society which funded sequencing and greenhouse charges. The Kuwaiti Government funded a Graduate (Ph.D.) Scholarship for Jaser Aljaser to conduct this research as part of his Ph.D. dissertation.

\section{Authors' contributions}

NOA directed the entire research project. JAA and NOA designed the research. JAA performed the experimentation, while JAA and AKN analyzed the data. JAA and NOA wrote the complete manuscript with equal contributions; AKN edited the manuscript along with NOA and JAA. All authors read and approved the final draft of the manuscript.

\section{Acknowledgements}

We sincerely thank Research Scientists Michele Schermann and Rajmund Eperjesi and undergraduate students, Allison Graper, Cora Rost, Sarah Gardner, and Betty Ziskovsky for their time and work spent in growing the genotypes.

\section{References}

1. Kamenetsky R, Zaccai M, Flaishman MA. Florogenesis. In: Kamenetsky R, Okubo H., eds. Ornamental geophytes: from basic science to sustainable production. CRC Press, Boca Raton, FL; 2012. p. 197232.

2. Srikanth A, Schmid M. Regulation of flowering time: all roads lead to Rome. Cell Mol Life Sci. 2011;68(12):2013-2037.

3. Simpson GG, Dean C. Arabidopsis, the Rosetta stone of flowering time? Sci. 2002;296(5566):285289.

4. Simpson GG. The autonomous pathway: epigenetic and post-transcriptional gene regulation in the control of Arabidopsis flowering time. Cur Opin Plant Biol. 2004;7(5):570-574.

5. Levy YY, Mesnage S, Mylne JS, Gendall AR, Dean C. Multiple roles of Arabidopsis VRN1 in vernalization and flowering time control. Sci. 2002;297(5579):243-246.

6. Lee JH, Yoo SJ, Park SH, Hwang I, Lee JS, Ahn JH. Role of SVP in the control of flowering time by ambient temperature in Arabidopsis. Genes and Dev. 2007;21(4):397-402.

7. Kumar G, Arya P, Gupta K, Randhawa V, Acharya V, Singh AK. Comparative phylogenetic analysis and transcriptional profiling of MADS-box gene family identified DAM and FLC-like genes in apple (Malus x domestica). Sci Rep. 2016;6:20695.

8. Guo X, Yu C, Luo L, Wan H, Zhen N, Xu T, et al. Transcriptome of the floral transition in Rosa chinensis 'Old Blush'. BMC Genomics 2017;18(1):199.

9. de Oliveira RR, Cesarino I, Mazzafera P, Dornelas MC. Flower development in Coffea arabica L.: new insights into MADS-box genes. Plt Reprod. 2014;27(2):79-94. 
10. Tadege M, Sheldon CC, Helliwell CA, Stoutjesdijk P, Dennis ES, Peacock WJ. Control of flowering time by FLC orthologues in Brassica napus. Plt J. 2001;28(5):545-553.

11. Choi K, Kim J, Hwang HJ, Kim S, Park C, Kim SY et al. The FRIGIDA complex activates transcription of $F L C$, a strong flowering repressor in Arabidopsis, by recruiting chromatin modification factors. Plt Cell 2011;23(1):289-303.

12. Michaels SD, Himelblau E, Kim SY, Schomburg FM, Amasino RM. Integration of flowering signals in winter-annual Arabidopsis. Plt Phys. 2005;137(1):149-156.

13. Michaels SD, Amasino RM. FLOWERING LOCUS C encodes a novel MADS domain protein that acts as a repressor of flowering. Plt Cell 1999;11:949-956.

14. Levy YY, Mesnage S, Mylne JS, Gendall AR, Dean C. Multiple roles of Arabidopsis VRN1 in vernalization and flowering time control. Sci. 2002;297(5579):243-246.

15. Turner AS, Faure S, Zhang Y, Laurie DA. The effect of day-neutral mutations in barley and wheat on the interaction between photoperiod and vernalization. Theor Appl Genet. 2013;126(9):2267-2277.

16. Yan L, Loukoianov A, Blechl A, Tranquilli G, Ramakrishna W, SanMiguel P, et al. The wheat VRN2 gene is a flowering repressor down-regulated by vernalization. Sci. 2004;303(5664):1640-1644.

17. Zhu QH, Helliwell CA. Regulation of flowering time and floral patterning by miR172. J Exptl Bot. 2011;62(2):487-495.

18. Ehrich L. Flowering in South African Iridaceae. In: Ramawat KG, Merillon JM, eds. Bulbous plants: Biotechnology. CRC Press, Boca Raton, FL. 2013;p. 248-269.

19. Fadón E. Herrero M, Rodrigo J. Flower bud dormancy in Prunus species. In: Anderson JV, ed. Advances in plant dormancy. Springer, The Netherlands. 2015;p. 123-135.

20. Taylor A. Functional genomics of photoperiodic bulb initiation in onion (Allium cepa). Univ of Warwick, U.K. 2009; PhD Dissertation.

21. Taylor A, Massiah AJ, Thomas B. Conservation of Arabidopsis thaliana photoperiodic flowering time genes in onion (Allium cepa L.). Plt Cell Phys. 2010;51(10):1638-1647.

22. Noy-Porat T, Flaishman MA, Eshel A, Sandler-Ziv D, Kamenetsky R. Florogenesis of the Mediterranean geophyte Narcissus tazetta and temperature requirements for flower initiation and differentiation. Sci Hort. 2009;120(1):138-142.

23. Noy-Porat T, Kamenetsky R, Eshel A, Flaishman MA. Temporal and spatial expression patterns of the LEAFY homologue NLF during florogenesis in Narcissus tazetta. Plt Sci. 2010;178(2):105-113.

24. Rotem N, Shemesh E, Peretz Y, Akad F, Edelbaum O, Rabinowitch HD, et al. Reproductive development and phenotypic differences in garlic are associated with expression and splicing of $L E A F Y$ homologue gaLFY. J Exp Bot. 2007;58(5):1133-1141. doi:10.1093/jxb/erl272.

25. Rotem N, David-Schwartz R, Peretz Y, Sela I, Rabinowitch HD, Flaishman M, et al. Flower development in garlic: the ups and downs of gaLFY expression. Planta 2011;233(5):1063-1072.

26. Wang AJ, Tang JF, Zhao XY, Zhu LH. Isolation of LiLFY1 and its expression in lily (Lilium longiflorum Thunb.). Agric Sci China 2008;7(9):1077-1083. 
27. Li YF, Zhang MF, Zhang M, Jia GX. Analysis of global gene expression profiles during the flowering initiation process of Lilium $\times$ formolongi. Plt Mol Biol. 2017;94(4-5):361-379.

28. Zlesak D, Anderson NO. Inheritance of non-obligate vernalization requirement for flowering in Lilium formosanum Wallace. Isr J Plt Sci. 2010;57(4):315-327.

29. Cohat J. Gladiolus. In: De Hertogh A, Le Nard M, eds. The physiology of flower bulbs. Elsevier, Amsterdam. 1993;p. 297-320.

30. Kamo KK, Krens FA, Ziv M. Biotechnology for the modification of horticultural traits in geophytes. In: Kamenetsky R, Okubo H, eds. Ornamental geophytes: from basic science to sustainable production. CRC Press, Boca Raton, FL. 2012:p. 159-195.

31. Luo X, Lu H, Yuan L, Jia Y, Wu Y, Deng Q. Cloning and expression analysis of gibberellin receptor gene in Gladiolus hybridus. Acta Bot. Boreali-Occid Sinica 2016;36(11):2152-2158.

32. Blázquez MA, Weigel D. Integration of floral inductive signals in Arabidopsis. Nature 2000;404(6780):889-892.

33. Lee J, Amasino RM. Two $F L X$ family members are non-redundantly required to establish the vernalization requirement in Arabidopsis. Nat Comm. 2013;4:2186. doi:10.1038/ncomms3186.

34. Zhao T, Ni Z, Dai Y, Yao Y, Nie X, Sun Q. Characterization and expression of 42 MADS-box genes in wheat (Triticum aestivum L.). Mol Genet Genom. 2006:276(4):334.

35. Monteagudo A, Igartua E, Contreras-Moreira B, Gracia MP, Ramos J, Karsai I, et al. Fine-tuning of the flowering time control in winter barley: the importance of HvOS2 and HvVRN2 in non-inductive conditions. BMC Plt Biol. 2019;19(1):1-14.

36. Ruelens P, De Maagd RA, Proost S, Theißen G, Geuten K, Kaufmann K. FLOWERING LOCUS C in monocots and the tandem origin of angiosperm-specific MADS-box genes. Nat Comm. 2013;4(1):1-8.

37. Finnegan EJ, Sheldon CC, Jardinaud F, Peacock WJ, Dennis ES. A cluster of Arabidopsis genes with a coordinate response to an environmental stimulus. Cur Biol. 2004;14(10):911-916.

38. Sheldon CC, Finnegan JE, Peacock JW, Dennis ES. Mechanisms of gene repression by vernalization in Arabidopsis. Plt J. 2009;59(3):488-498.

39. Yoshida S, Van Der Schuren A, Van Dop M, Van Galen L, Saiga S, Adibi M, et al. A SOSEKI-based coordinate system interprets global polarity cues in Arabidopsis. Nat Plts. 2019;5(2):160-166. doi:10.1038/s41477-019-0363-6.

40. Chengke L, Lei T. Bioinformatics analysis of rice DUF966 gene family. Mol Plt Br. 2017;15(12):47914796.

41. Ye J, Zhong T, Zhang D, Ma C, Wang L, Yao L, et al. The auxin-regulated protein ZmAuxRP1 coordinates the balance between root growth and stalk rot disease resistance in maize. Mol Plt. 2019;12(3):360-373.

42. Andersson CR, Helliwell CA, Bagnall DJ, Hughes TP, Finnegan EJ, Peacock WJ, Dennis ES. The FLX gene of Arabidopsis is required for FR-dependent activation of FLC expression. Plt Cell Phys. 2008;49(2):191-200. 
43. Anderson NO, Carter J, Hershman A, Houseright V. Rapid generation cycling enhances selection rate of Gladiolus xhybridus. Acta Hort. 2015;1087:429-435.

44. Anderson NO. Selection tools for reducing generation time of geophytic herbaceous perennials. XIII International Symposium on Flower Bulbs and Herbaceous Perennials, Acta Hort. 2019;1237:53-66.

45. Aljaser JA. Gladiolus breeding for rapid generation cycling for potted production and the discovery of gladiolus genes, UFC and FLX. Univ. Minnesota, Minneapolis, MN, USA. PhD. Dissertation.

46. Bamford R. The chromosome number in Gladiolus. J Agr Res. 1935;51:945-950.

47. Saito K, Kusakari, K. Studies on the occurrence of polyploidy and its contribution to the flower plants breeding: IX. Cytological observations on the mechanism of decreased fertility in the summerflowering tetraploid cultivars of Gladiolus grandiflorus Hort. Jap J Breed. 1972;22(2):75-82.

48. Ohri D. Cytogenetics of garden gladiolus. Cytol. 1985;50(2):213-231.

49. Benschop M, Kamenetsky R, Le Nard M, Okubo H, De Hertogh, A. The global flower bulb industry: Production, utilization, research. Hort Rev. 2010;36(1):1-115.

50. Goldblatt P, Manning J. Gladiolus in southern Africa. Fernwood Press (Pty) Ltd., Newburg, OR. 1998.

51. Amasino RM, Michaels SD. The timing of flowering. Plt Phys. 2010;154(2):516-520.

52. Cohen A, Barzilay A. Miniature gladiolus cultivars bred for winter flowering. HortSci. 1991;26(2):216218.

53. Gonzalez A, Banon S, Fernandez JA, Franco JA, Casas JL, Ochoa J. Flowering responses of Gladiolus tristis (L.) after exposing corms to cold treatment. Sci Hort. 1998;74(4):279-284.

54. Goldblatt P. Gladiolus in tropical Africa: Systematics, biology and evolution. Timber Press, Portland, OR. 1996.

55. Wayside Gardens. Gladiolus Glamini® Mixed. 2020. https://www.waysidegardens.com/glaminimixed-gladiolus/p/27192-PK-10/

56. Old House Gardens. Gladiolus: Lost forever? 2020. https://oldhousegardens.com/display/category/BackSoonGladiolus?bulb=SGL30

57. National Center for Biotechnology Information. Accession No. XM_009383889.2, PREDICTED: Musa acuminata subsp. malaccensis protein UPSTREAM OF FLC (LOC103970210), transcript variant X1, mRNA. 2016a. https://www.ncbi.nlm.nih.gov/nuccore/XM_009383889

58. National Center for Biotechnology Information. Accession No. XM_010920607.2, PREDICTED: protein UPSTREAM OF FLC [Elaeis guineensis]. 2017a. https://www.ncbi.nlm.nih.gov/nuccore/XM_010920607.2

59. National Center for Biotechnology Information. Accession No. XM_010924316.2, protein FLC EXPRESSOR[Elaeis guineensis]. 2017b. https://www.ncbi.nlm.nih.gov/nuccore/XM_010924316.2

60. National Center for Biotechnology Information. Accession No. XM_008801571.2, PREDICTED: protein FLOWERING LOCUC C EXPRESSOR-like [Phoenix dactylifera]. 2016b.

https://www.ncbi.nlm.nih.gov/nuccore/XM_008801571.2 
61. Zimin AV, Marçais G, Puiu D, Roberts M, Salzberg SL, Yorke JA. The MaSuRCA genome assembler. Bioinfo. 2013;29(21):2669-2677.

62. Xu H, Yu Q, Shi Y, Hua X, Tang H, Yang L, et al. PGD: pineapple genomics database. Hort Res. 2018;5(1):1-9. Pineapple Genomics Database http://pineapple.angiosperms.org/pineapple/html/index.html

63. Droc G, Lariviere D, Guignon V, Yahiaoui N, This D, Garsmeur O, et al. The Banana Genome Hub Database. 2013. doi:10.1093/database/bat035

64. Sanusi NSNM, Rosli R, Halim MAA, Chan KL, Nagappan J, Azizi N, et al. PalmXplore: oil palm gene database. 2018. http://palmxplore.mpob.gov.my

65. Harkess A, Zhou J, Xu C, Bowers JE, Van der Hulst R, et al. The asparagus genome sheds light on the origin and evolution of a young $Y$ chromosome. Nat Comm. 2017;8(1):1-10. http://asparagus.uga.edu/

66. The Arabidopsis Information Resource (TAIR). The Arabidopsis Information Resource (TAIR). 2020. https://www.arabidopsis.org/servlets/TairObject?id=136005andtype=locus

67. Grant D, Nelson RT, Cannon SB, Shoemaker C. SoyBase, the USDA-ARS soybean genetics and genomics database. Nucl Acids Res. 2010;38(suppl 1):D843-D846. https://www.soybase.org/ doi:10.1093/nar/gkp798.

68. National Center for Biotechnology Information. Accession No. XP_020095672.1, protein FLX-like 1 [Ananas comosus]. 2017c. https://www.ncbi.nlm.nih.gov/protein/XP_020095672.1

69. National Center for Biotechnology Information. Accession No. XP_009420070.1, PREDICTED: protein FLX-like 1 [Musa acuminata subsp. malaccensis]. 2016c.

https://www.ncbi.nlm.nih.gov/protein/695063148

70. National Center for Biotechnology Information. Accession No. XP_010922618.1, protein FLC EXPRESSOR [Elaeis guineensis]. 2019a. https://www.ncbi.nlm.nih.gov/protein/XP_010922618.1

71. National Center for Biotechnology Information. Accession No. NP_001154541.1, protein FLC EXPRESSOR [Arabidopsis thaliana]. 2019b. https://www.ncbi.nlm.nih.gov/protein/NP_001154541.1

72. National Center for Biotechnology Information. Accession No. NP_566492.1, structural maintenance of chromosomes domain protein [Arabidopsis thaliana]. 2019c. https://www.ncbi.nlm.nih.gov/protein/NP_566492.1

73. National Center for Biotechnology Information. Accession No. NP_001320766.1, sarcolemmal membrane-associated protein [Arabidopsis thaliana]. 2019d. https://www.ncbi.nlm.nih.gov/protein/NP_001320766.1

74. National Center for Biotechnology Information. Accession No. NP_564678.1, DNA double-strand break repair protein [Arabidopsis thaliana]. 2019e. https://www.ncbi.nlm.nih.gov/protein/NP_564678.1

75. National Center for Biotechnology Information. Accession No. NP_001119474.1, FLX-like protein [Arabidopsis thaliana]. 2019f. https://www.ncbi.nlm.nih.gov/protein/NP_001119474.1 
76. Kelley LA, Mezulis S, Yates CM, Wass MN, Sternberg MJ. The Phyre2 web portal for protein modeling, prediction and analysis. Nat Protocols 2015;10(6):845-858.

http://www.sbg.bio.ic.ac.uk/ phyre2/html/page.cgi?id=index

\section{Tables}

Table 1. The Gladiolus genotypes used in this study, their codes and whether they are Rapid Generation Cycling (RGC): + is for RGC genotypes and - for Non-RGC genotypes; all gladiolus genotypes were tested for the presence of UFC gene, FLX gene and FR/gene.

\begin{tabular}{|lll|}
\hline Genotype & Code & RGC \\
\hline Gladiolus $\times$ hybridus 21213 & 1 & + \\
\hline Gladiolus $\times$ hybridus 2220 & 2 & + \\
\hline Gladiolus $\times$ hybridus 2231 & 3 & + \\
\hline Gladiolus $\times$ hybridus 2337 & 4 & + \\
\hline Gladiolus $\times$ hybridus 35314 & 5 & + \\
\hline Gladiolus $\times$ hybridus 3923 & 6 & + \\
\hline Gladiolus $\times$ hybridus 3931 & 7 & + \\
\hline Gladiolus $\times$ hybridus 74210 & 8 & + \\
\hline Gladiolus $\times$ hybridus 7736 & 9 & + \\
\hline Gladiolus $\times$ hybridus 28236 & 10 & - \\
\hline Gladiolus $\times$ hybridus 15531 & 11 & - \\
\hline Gladiolus $\times$ hybridus 20732 & 12 & - \\
\hline Gladiolus $\times$ hybridus 60314 & 13 & - \\
\hline Gladiolus dalenii 'Carolina Primrose' & 14 & - \\
\hline Gladiolus $\times$ hybridus 'Beatrice' & 15 & - \\
\hline Gladiolus $\times$ hybridus 'Glamini' ${ }^{8}$ & 16 & - \\
\hline Gladiolus $\times$ hybridus ${ }^{\prime}$ Vista & 17 & - \\
\hline
\end{tabular}

Table 2. The identity of amino acid sequences and number (\%) of two UFC proteins (GhUFC-A, GhUFC-B) in two Gladiolus (genotypes 1 and 15) in relation to other species (Gene locus/ID) through pair alignment; the similarities of sequences in identity of gladiolus genotypes ranges from $\sim 30 \%$ to $57 \%$ across all 
investigated species for the whole UFC protein; alignment is done with MUSCLE alignment using the neighbor joining clustering method and the CLUSTALW sequencing scheme (Geneious®).

Gladiolus $\times$ hybridus genotype

\begin{tabular}{lllll} 
& \multicolumn{3}{c}{ Gladiolus $\times$ hybridus genotype } \\
\cline { 2 - 5 } Species (Gene locus/ID) & GhUFC-A (\%) & GhUFC-B (\%) & GhUFC-A (\%) & GhUFC-B (\%) \\
\hline Ananas comosus (Aco009327) & $189(33.51 \%)$ & $249(53.21 \%)$ & $191(34.35 \%)$ & $231(52.98 \%)$ \\
Musa acuminata (GSMUA_Achr5T28540_001) & $251(54.09 \%)$ & $170(39.35 \%)$ & $250(57.74 \%)$ & $148(31.36 \%)$ \\
Elaeis guineensis (p5.00_sc00099_p0095) & $254(52.05 \%)$ & $172(40.86 \%)$ & $250(51.23 \%)$ & $155(39.85 \%)$ \\
Asparagus officinalis (evm.model.AsparagusV1_08.3493) & $213(46.61 \%)$ & $148(35.58 \%)$ & $213(50.0 \%)$ & $135(29.87 \%)$ \\
Arabidopsis thaliana (AT5G10150) & $137(28.54 \%)$ & $129(29.79 \%)$ & $138(31.72 \%)$ & $117(29.32 \%)$ \\
Glycine max (Glyma.11G193000.1) & $181(33.64 \%)$ & $226(52.19 \%)$ & $188(35.67 \%)$ & $207(52.01 \%)$ \\
& & & & \\
\hline
\end{tabular}

Table 3. Identity of amino acid sequences, number (\%) of UFC proteins in the conserved domain DUF966 in Gladiolus genotypes 1 and 15 in relation to other species through pair alignment. Gladiolus genotypes 1 and 15 exhibit a range of $\sim 65 \%$ to $\sim 86 \%$ across all investigated species for the DUF966 domain of UFC protein.

Gladiolus $\times$ hybridus genotype

\begin{tabular}{lcccc} 
& \multicolumn{3}{c}{ Gladiolus $\times$ hybridus genotype } \\
\cline { 2 - 5 } Species (Gene locus/ID) & Genotvpe 1 & \multicolumn{2}{c}{ Genotvpe 15 } \\
Ananas comosus (Aco009327) & $70(76.09 \%)$ & $79(84.95 \%)$ & $79(84.95 \%)$ & $79(84.95 \%)$ \\
Musa acuminata (GSMUA_Achr5T28540_001) & $78(84.78 \%)$ & $71(78.02 \%)$ & $78(84.78 \%)$ & $71(78.02 \%)$ \\
Elaeis guineensis (p5.00_sc00099_p0095) & $79(85.87 \%)$ & $72(79.12 \%)$ & $79(85.87 \%)$ & $72(79.12 \%)$ \\
Asparagus officinalis (evm.mode1.AsparagusV1_08.3493) & $75(82.42 \%)$ & $70(76.09 \%)$ & $75(82.42 \%)$ & $70(76.09 \%)$ \\
Arabidopsis thaliana (AT5G10150) & $61(66.30 \%)$ & $61(64.89 \%)$ & $62(67.39 \%)$ & $61(64.89 \%)$ \\
Glycine max (Glyma.11G193000.1) & $70(76.92 \%)$ & $75(82.42 \%)$ & $70(76.92 \%)$ & $75(81.52 \%)$ \\
& & & & \\
\hline
\end{tabular}

Table 4. Number (\%) of amino acid sequences of GhFLX protein in Gladiolus genotypes 3 and 6 (genotype 16 is identical to genotype 6) in relation to the other species through pair alignment; similarities of sequences in identity of gladiolus genotypes ranged from $\sim 26 \%$ to $~ 65 \%$ across all investigated species of the whole FLX protein; alignment is done in MUSCLE, using the neighbor joining clustering method and the CLUSTALW sequencing scheme (Geneious $\left.{ }^{\circledR}\right)$. 
Species (Accession no.)

Ananas comosus (XP_020095672.1)

Musa acuminata (XP_009420070.1)

Elaeis guineensis (XP_010922618.1)

Arabidopsis thaliana - FLX (NP_001154541.1)

Arabidopsis thaliana - FLL1 (NP_566492.1)

Arabidopsis thaliana - FLL2 (NP_001320766.1)

Arabidopsis thaliana - FLL3 (NP_564678.1)

Arabidopsis thaliana - FLL4 (NP_001119474.1)

Glycine max (Glyma.15g269300)
GhFLX Genotype 3 (\%)

$180(64.98 \%)$

$122(48.03 \%)$

$132(50.00 \%)$

$82(30.48 \%)$

$135(50.00 \%)$

$96(36.09 \%)$

$104(34.67 \%)$

$67(26.38 \%)$

$156(57.14 \%)$
GhFLX Genotype 6 and $16(\%)$

$177(64.60 \%)$

$122(48.03 \%)$

$131(49.62 \%)$

$82(30.48 \%)$

$135(50.00 \%)$

$94(35.34 \%)$

$104(34.67 \%)$

$68(26.77 \%)$

$155(56.78 \%)$

\section{Figures}

In Arabidopsis and temperate dicots

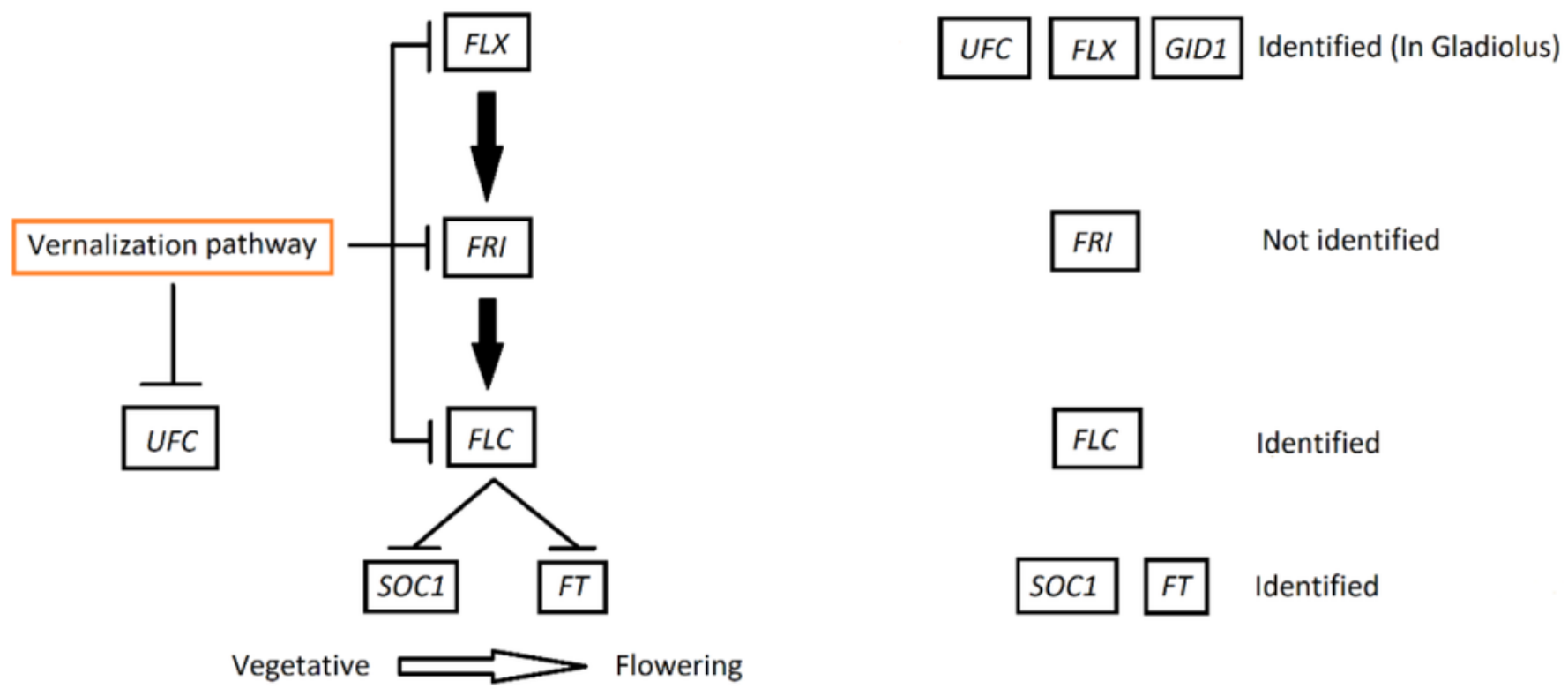

\section{Figure 1}

Model represents portion of flowering pathway regarding the role of FLX gene in flowering along with UFC gene in Arabidopsis and temperate dicots. FLX upregulates FRI which also upregulates the expression of the FLC protein and suppresses flowering by repressing the expression of the floral integrator SOC1 and FT. Vernalization pathway downregulates the expression of FLX, FRI and FLC genes allowing the floral integrators to initiate flowering in vegetative state of dicots, while the vernalization pathway also 
downregulates the UFC gene [37]. In monocots, FLX, FLC, SOC1 and FT have been identified [22,35,51], while UFC and FLX have just been identified in gladiolus (in the current experiments). However, FRI was not identified either by lacking the presence of these repressor genes or monocots relying on other options of the flowering pathway genes.

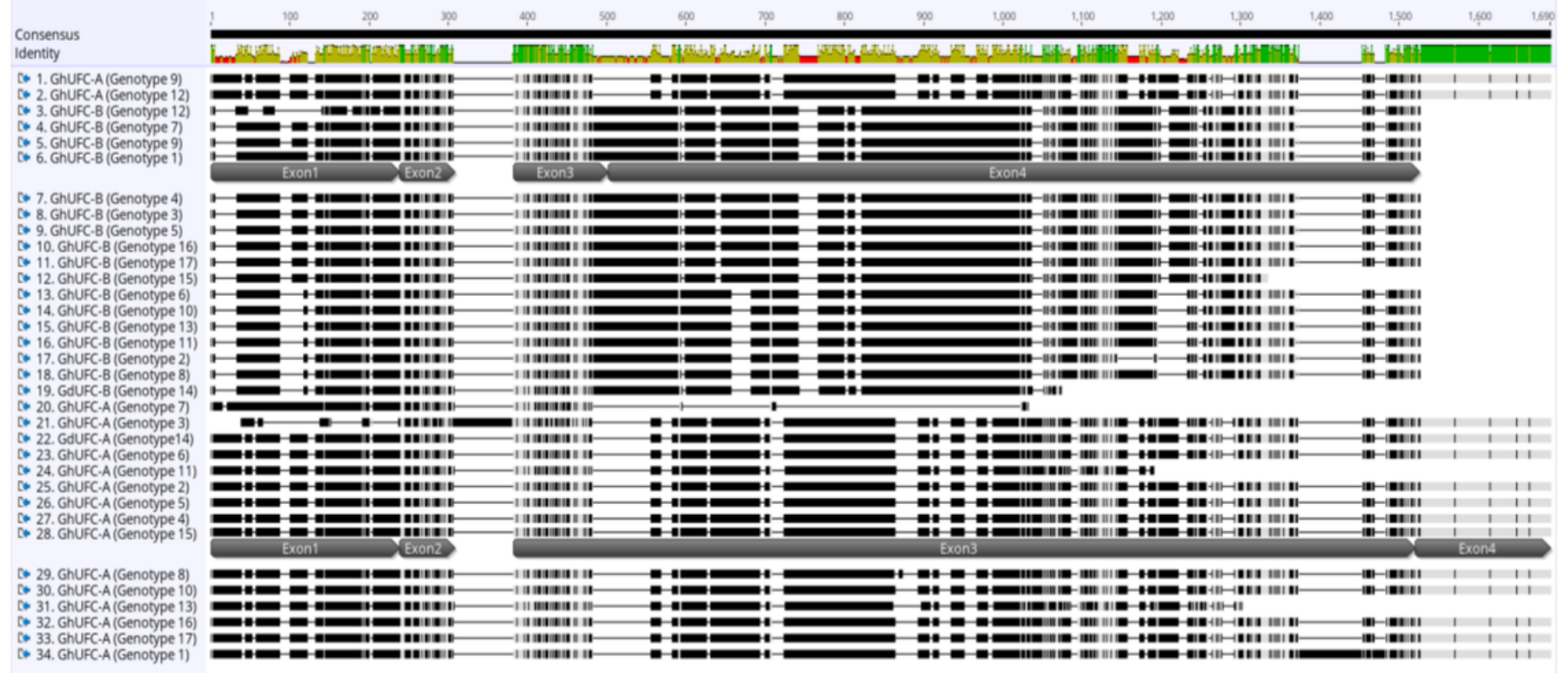

Figure 2

Multi-alignment of UFC coding sequence in Gladiolus xhybridus (GhUFC) and Gladiolus dalenii (GdUFC), the alignment is for the 17 genotypes, each genotype has 2 alleles, allele A and allele B: GhUFC-A, GdUFCA, GhUFC-B, GdUFC-B. Both alleles has 4 exons but allele A size is larger in coding sequence than allele B. The alignment shows insertion and missing coding sequences in some genotypes. The multi-alignment is done in MUSCLE pair-alignment using neighbor joining cluster method and CLUSTALW sequencing scheme (Geneious) ${ }^{\circledR}$

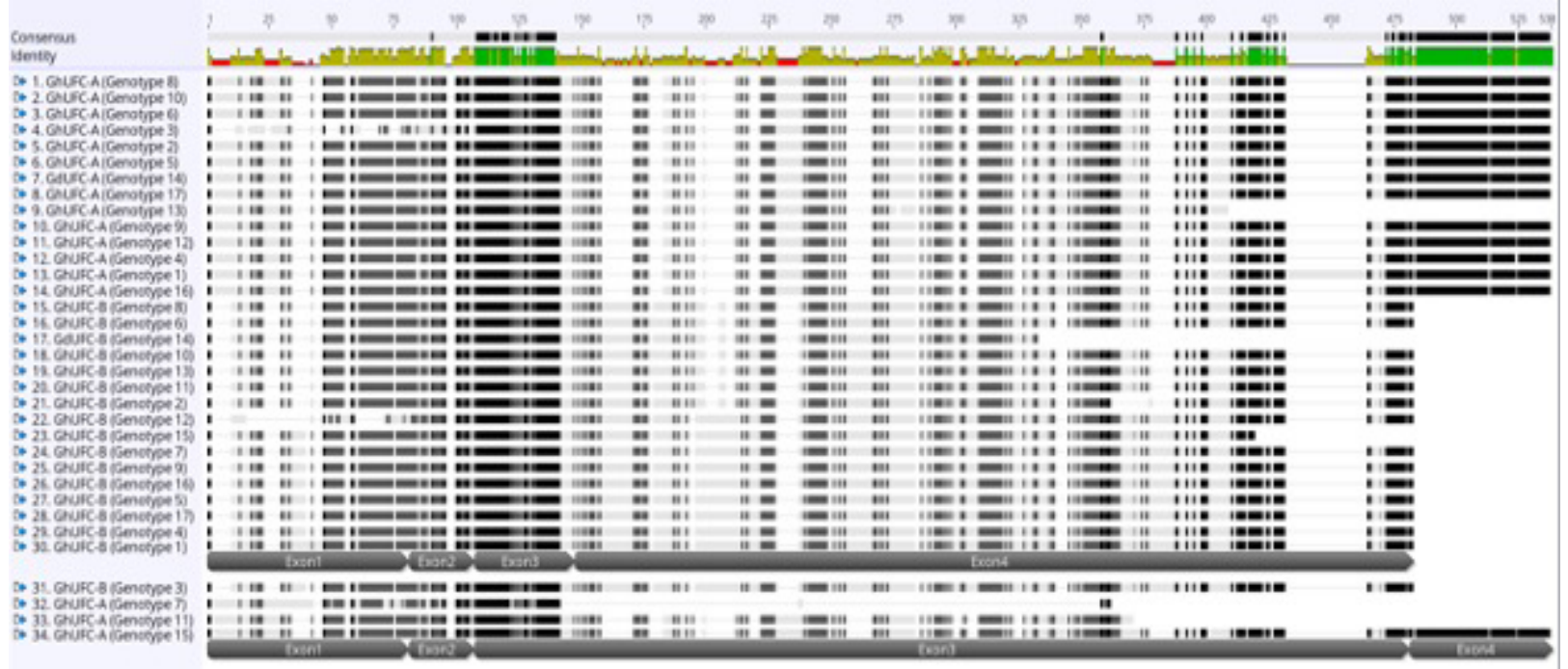

Figure 3 
Multi-alignment of UFC amino acid sequence in Gladiolus xhybridus (GhUFC) and Gladiolus dalenii (GdUFC), the alignment is for the 17 genotypes, each genotype has 2 alleles, allele A and allele B: GhUFCA, GdUFC-A, GhUFC-B, GdUFC-B. Both alleles has 4 exons but allele A size is larger in amino acid sequence than allele $B$. The alignment shows insertion and missing amino acid sequences in some genotypes. The alignment identify conserved amino acid sequences (green color). The multi-alignment is done in MUSCLE pair-alignment using neighbor joining cluster method and CLUSTALW sequencing scheme (Geneious)®

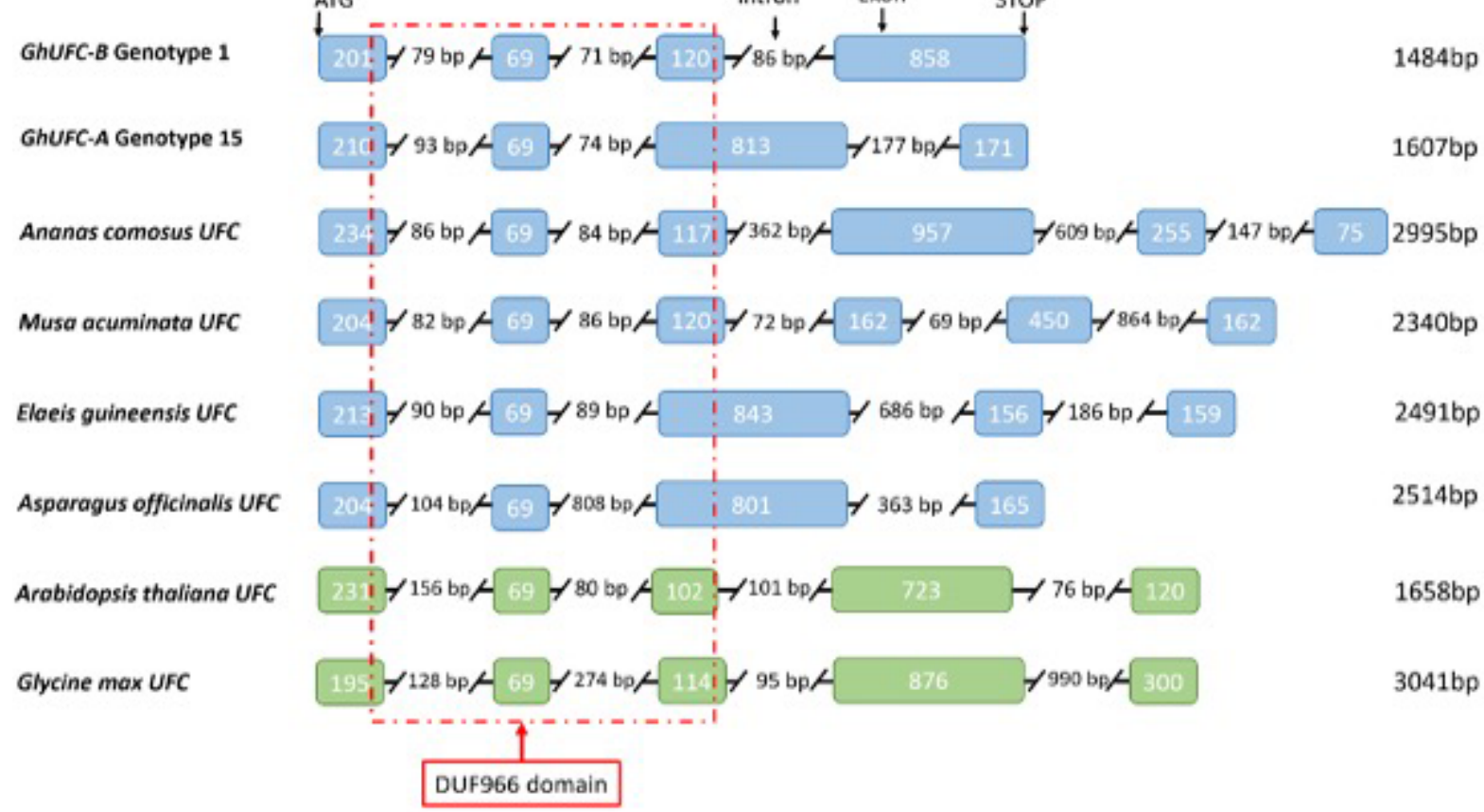

\section{Figure 4}

Intron-exon configuration of the UFC genes in Gladiolus xhybridus of genotypes 1 and 15 in relation to several species. Monocot species are highlighted in blue: Ananas comosus, Musa acuminata, Elaeis guineensis and Asparagus officinalis. Dicot species highlighted in green for Arabidopsis thaliana and Glycine max. The intron-exon organization of GhUFC-A genotype 15 is similar to Elaeis guineensis and Asparagus officinalis in terms of exons splicing while GhUFC-B genotype 1 has some similarity with Ananas comosus exons. Sequences were aligned based on first exon sequences. Total length of the gene's coding region is listed on the right of each respected species. The red line represents the conserved domain DUF966 in relation to the location of the domain with exon configuration.

Censensus

GuFc-B (Genotype 1)

Qunce-A (Geotype 15)

Ananas conosus UFC

Moa acueinuta UFC

Claeis puineensis UFC

(p5,00,sc0099.,0095)

Asparagus officinalis UFC (eve.nedel.AsparaqusV e8. 3993)

Arabidopsis thaliana bire (ATS6:Biso)

Glycine eax UFC

(Glyw.116193009.1) $\begin{array}{lllllllllll}53 & 63 & 73 & 83 & 93 & 103 & 113 & 123 & 133 & 143 & 106\end{array}$

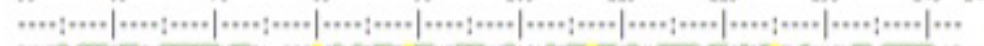

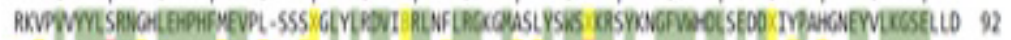

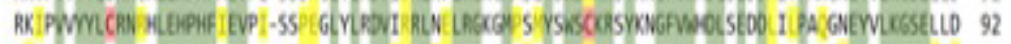

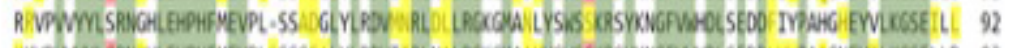

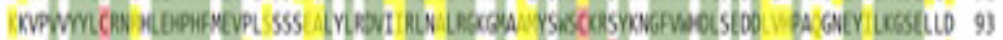

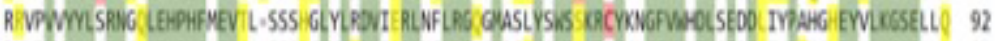

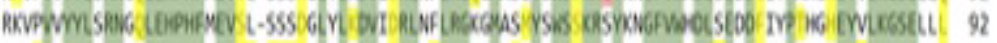

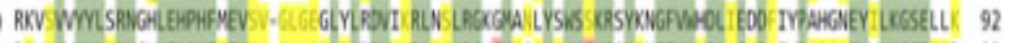

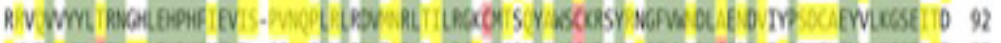

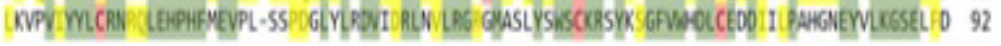




\section{Figure 5}

Alignment of the globular region containing DUF966 domain of UFC proteins from Gladiolus xhybridus of genotypes 1 and 15, Ananas comosus, Musa acuminata, Elaeis guineensis Asparagus officinalis, Arabidopsis thaliana and Glycine max. Green coloration shows identical amino acid sequence; yellow color highlights the polymorphisms while red color shows the cytosine amino acid. The conserved domain DUF966 is 92 amino acids.

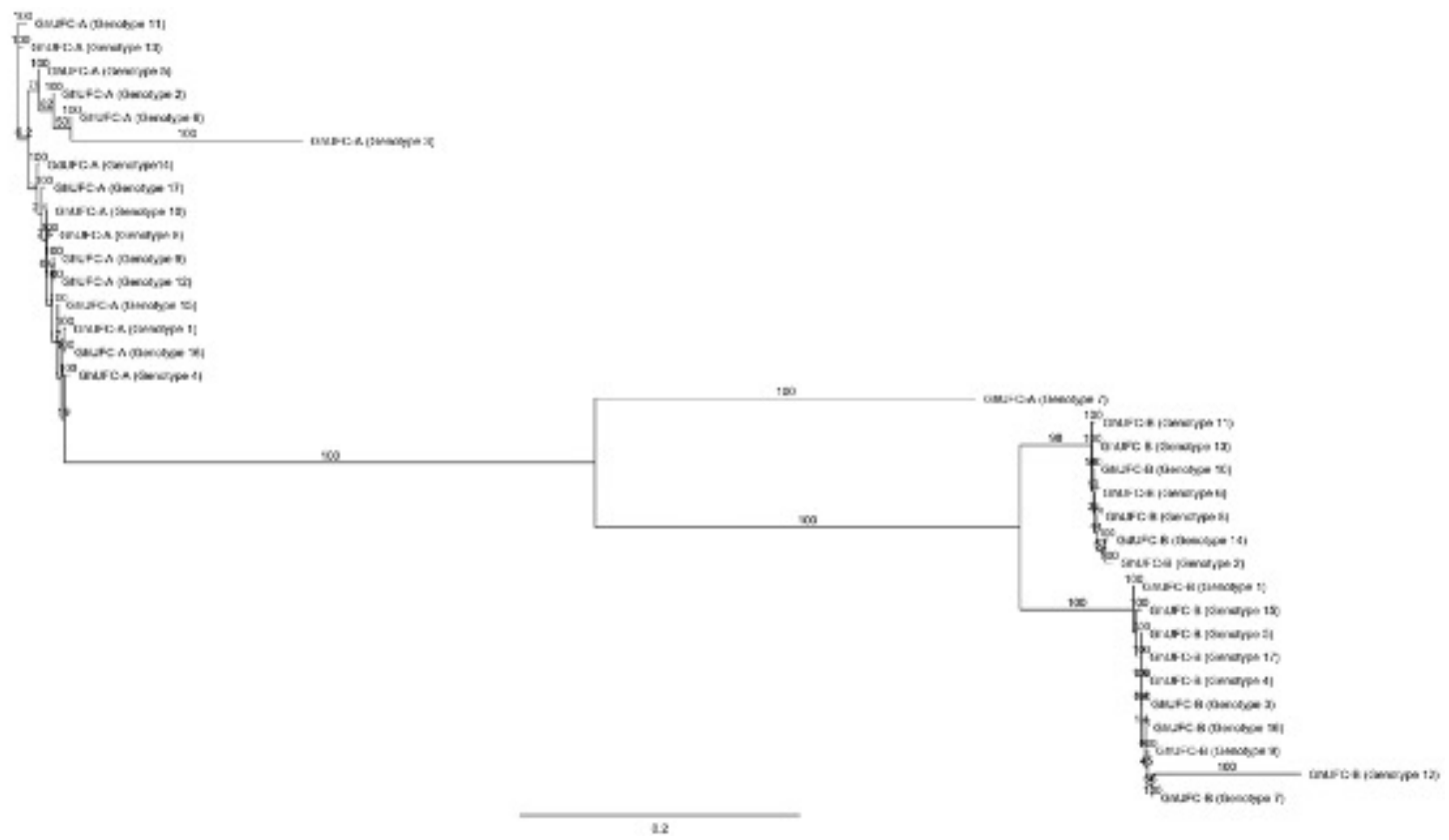

\section{Figure 6}

The phylogenetic tree of all UFC genotypes in Gladiolus; genetic distances were computed using the Tamura-Nei method and are in the units of the number of base substitutions per site. The tree build using the Neighbor-Joining method and the bootstrap test was performed for each tree (500 replicates) and the tree format is organized and ordered with a scale bar of 0.2 (Geneious ${ }^{\circledR}$ ).

\begin{tabular}{|c|}
\hline \\
\hline D. Thru, Gematype to \\
\hline 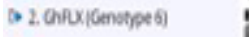 \\
\hline 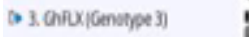 \\
\hline D. 4. Anunar comosas $\cdot \mathrm{PX}$ \\
\hline 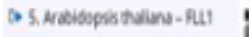 \\
\hline D. 6. Oponemar. $2 x$ \\
\hline D. 1, Bass puineeras - Rx \\
\hline D. 8. Hea ionmina $\cdot f X$ \\
\hline D. 9. Natisopsistulion - Ru \\
\hline of 10. Nabidops tulans - Fx \\
\hline D. 11. Nabidopss falans - F.12 \\
\hline D. 12 Nabidepsis tulums - Fu \\
\hline
\end{tabular}

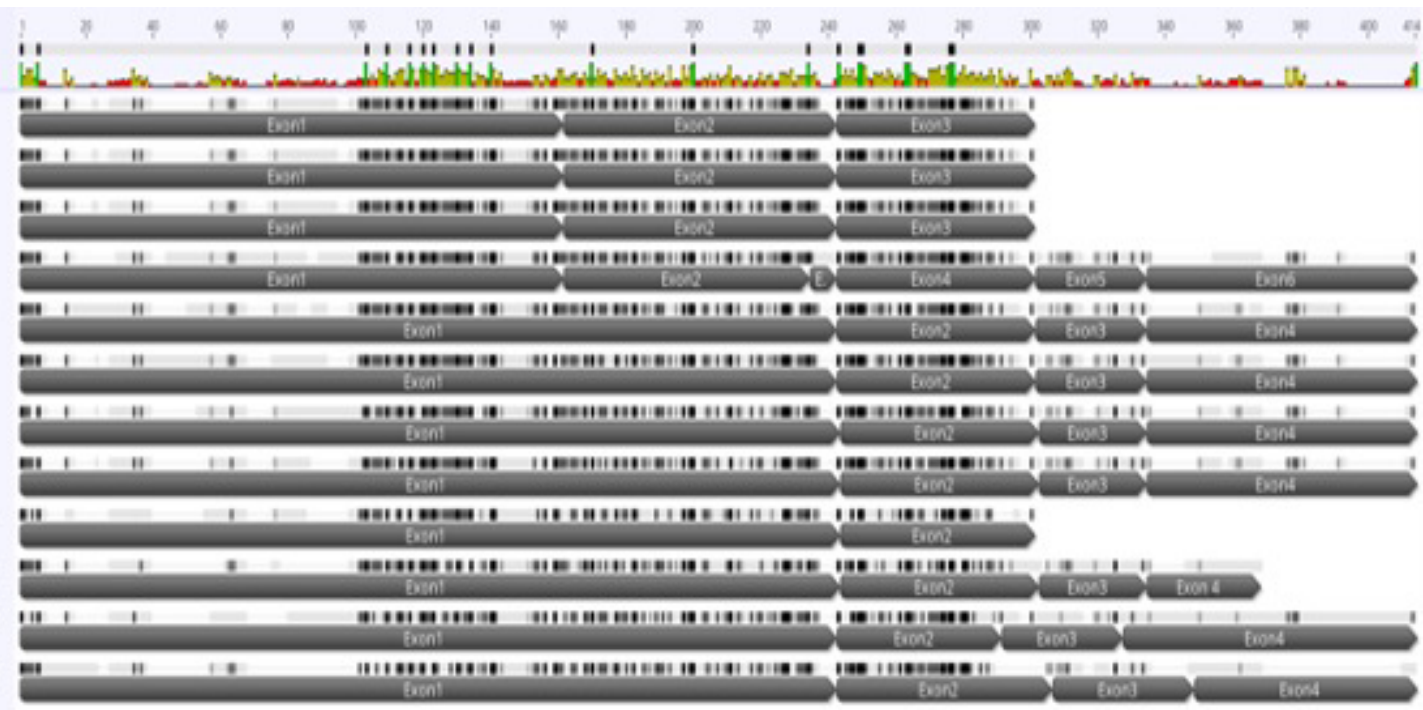

Figure 7 
Multi-alignment of FLX amino acid sequence in Gladiolus xhybridus (GhFLX) with other species; Arabidopsis thaliana, Ananas comosus, Elaeis guineensis, Musa acuminata and Glycine max. The alignment is for the 3 gladiolus genotypes (3,6 and 16) each genotype has 3 exons. The alignment shows missing amino acid sequences in gladiolus genotypes 3, 6 and 16 as amino acid sequences does not have a stop codon. The alignment identifies conserved amino acid sequences (green color). Note Arabidopsis thaliana - FLL4 is a functional protein which has two exons only [33]. The multi-alignment is done in MUSCLE pair-alignment using neighbor joining cluster method and CLUSTALW sequencing scheme (Geneious) ${ }^{\circledR}$.
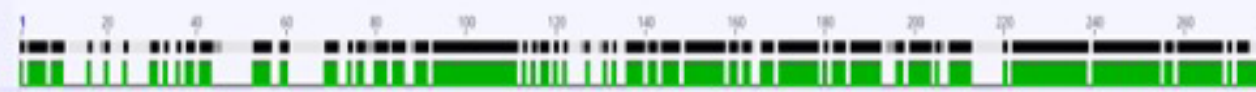

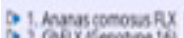
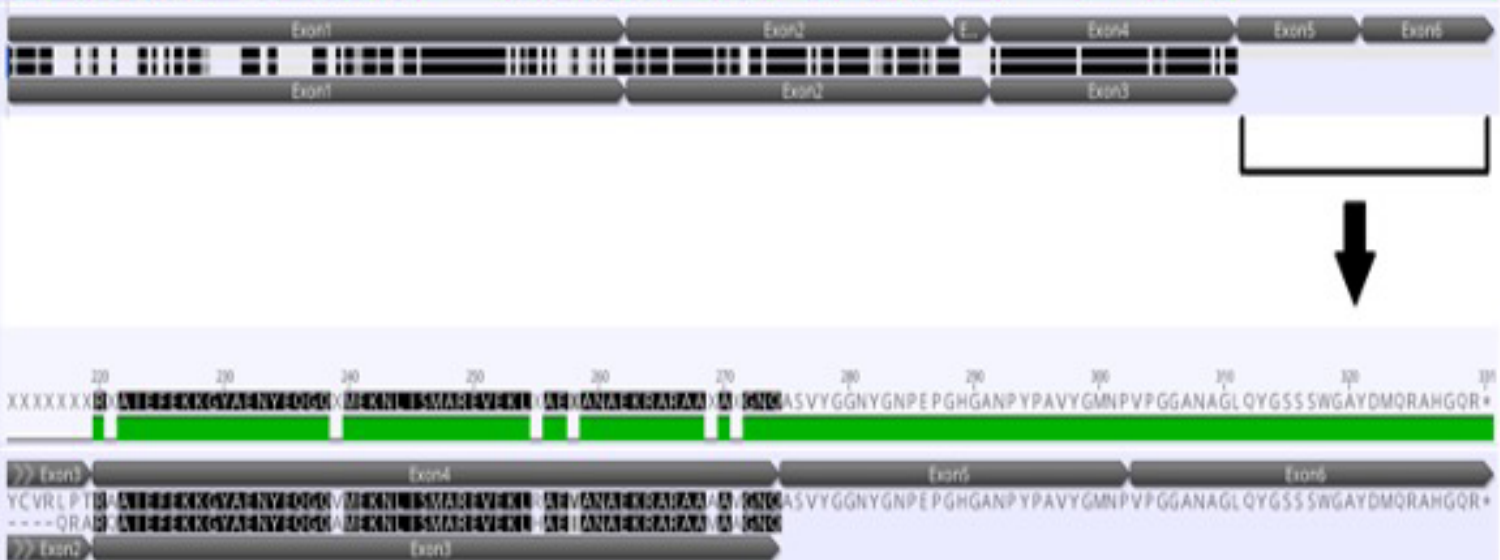

\section{Figure 8}

Pair alignment of FLX protein in Ananas comosus and Gladiolus xhybridus genotype 16 showing the complete FLX protein in Ananas comosus with five exons while incomplete FLX protein in Gladiolus xhybridus (GhFLX) which lacks the remaining two exons and stop codon. The alignment is done in MUSCLE pair-alignment using neighbor joining cluster method and CLUSTALW sequencing scheme (Geneious)®.

\section{Supplementary Files}

This is a list of supplementary files associated with this preprint. Click to download.

- AppendicesA1A3.pdf

- AppendicesA2A3originalgelpics.pdf 